УДК 616.12-007.2-053.2-07:618.33

\title{
Вплив пренатального діагнозу судинного кільця на перинатальне ведення та лікувальну тактику
}

\author{
Павлова А. О.
}

ДУ «Науково-практичний медичний центр дитячої кардіології та кардіохірургії МОЗ України» (Київ)

\begin{abstract}
Мета роботи - на основі проведеного аналізу ефективності пренатальної діагностики судинних кілець (СК) та оцінки клінічного стану пацієнтів створити алгоритм перинатальної тактики.

Матеріали та методи. 32004 по 2017 рр. було проведено 7740 первинних ехокардіографій (ЕхоКГ) плода. 3 2016 року при діагностиці СК проведено 21 магнітно-резонансну томографію (МРТ) плода.

Результати та обговорення. У 70 (0,9\%) випадках було діагностовано СК. У двох дітей спостерігалися симптоми стиснення трахеї та стравоходу відразу після народження, в інших - наростали поступово із 3-го місяця життя. Всього симптоми відмічались у 13 дітей. Було проведено аналіз і розроблено алгоритм ведення пацієнтів із пренатально діагностованим СК. Відсутність стиснення трахеї на МРТ плода дозволяє планувати пологи в пологовому будинку за місцем проживання та, при відсутності симптомів, консультувати дитину в Центрі в 1 місяць життя з плановим хірургічним лікуванням при стисненні трахеї на комп’ютерній томографії (КТ) більше 30\%. 3 появою симптомів обов’язковою є невідкладна консультація в Центрі. При наявності стиснення трахеї на МРТ плода - пологи поблизу кардіохірургічного центру та, з появою симптомів, невідкладна КТ і хірургічне лікування. Якщо СК не ізольоване, його усунення проводиться під час хірургічного лікування іншої вродженої вади серця (ВВС).
\end{abstract}

Висновки. При впровадженні у практику створеного алгоритму можна очікувати підвищення рівня надання допомоги дітям із СК.

Ключові слові: судинні кільия, ехокардіографія, пренатальна діагностика, магнітно-резонансна томографія, комп'ютерна томографія.

Щороку в ДУ «НПМЦДКК МОЗ України» проводиться в середньому 550 операцій у дітей першого року життя з ВВС, в тому числі у 185 новонароджених. У структурі смертності, пов'язаної з вродженими вадами розвитку, ВВС посідають перше місце. Оскільки наш Центр є лідером з хірургії ВВС у новонароджених в Україні, для покращення надання допомоги цій групі пацієнтів з 2004 р. вперше було розпочато програму пренатальної діагностики ВВС методом фетальної ЕхоКГ. Основним завданням даного нововведення була діагностика критичних і складних ВВС, оскільки вони є основною причиною смерті немовлят із ВВС. Із 2004 р. спостерігається щорічне зростання кількості обстежень вагітних, зокрема первинних консультацій. 3 розвитком пренатальної діагностики в нашому Центрі покращилася діагностика всіх ВВС, зокрема так званих дрібних аномалій, у тому числі й аномалій судин, таких як СК. Значним поштовхом до покращення пренатальної діагностики в 2011 році стало введення як обов'язкових проекцій трьох судин і трахеї, дуги аорти по довгій осі та високого поперекового зрізу черевної порожнини для визначення положення черевного відділу аорти [1-4]. Діагностика СК є важливою: хоча ця ВВС i вкрай рідко призводить до смерті, проте тривале не- діагностоване стиснення трахеї та стравоходу може спричинити інвалідизацію пацієнтів [5-7].

Мета роботи - на основі проведеного аналізу ефективності пренатальної діагностики СК та оцінки клінічного стану пацієнтів скласти алгоритм перинатальної та діагностично-лікувального тактики, в тому числі і хірургічного лікування.

Матеріали та методи. Із 2004 по 2017 рр. всього було проведено 7740 первинних обстежень вагітних. Усі обстеження проводилися методом трансабдомінальної ЕхоКГ плода на ультразвукових сканерах Philips Sonos 7500, Siemens Acuson Sequoia 512, Philips iU22, Philips EPIQ 7 за допомогою конвексних датчиків частотою 9-1 МГц. Із кінця 2016 року при діагностиці СК у 21 випадку проведено МРТ плода. Обстеження плода методом МРТ проводилося на томографі Siemens Avanto 1 5t. Комп'ютерна томографія (КТ) після народження проводилася на 16-зрізовому томографі Siemens Somatom Sensation.

Результати та обговорення. Діагноз СК з 2012 по 2017 pp. було запідозрено у $70(0,9 \%)$ випадках. Первинне обстеження проводилося при середньому терміні $26 \pm 5$ тижнів гестації (т.г.) (від 18-го до 38-го т.г.), з них до 22 т.г. ЕхоКГ плода проводилась у $29(41,4 \%)$ випадках, після - у $41(58,6 \%)$. У $62(88,6 \%)$ випадках було за- 


\section{Таблиця 1}

Поєднання СК з іншими ВBC

Bcboro

ПрДА, ЛАП, АЛПА 62 (88,6\%)

ПДА 8 (11,4\%)

\begin{tabular}{|c|c|c|}
\hline $\begin{array}{l}\text { Ізольоване СК } \\
\text { Поєднане з іншими ВВС }\end{array}$ & 49 & 6 \\
\hline \multirow[t]{8}{*}{ Поєднане з іншими ВВС } & 13 & 2 \\
\hline & $\begin{array}{l}1 \text { - ліва верхня порожниста вена, що дренується в коро- } \\
\text { нарний синус }\end{array}$ & $\begin{array}{l}1 \text { - ліва верхня порожниста вена, що } \\
\text { дренується в коронарний синус }\end{array}$ \\
\hline & $\begin{array}{l}1 \text { - корегована транспозиція великих артерій, } \\
\text { дефект міжшлуночкової перегородки, атрезія легеневої } \\
\text { артерії }\end{array}$ & 1 - дефект міжшлуночкової перегородки \\
\hline & $\begin{array}{l}1 \text { - обернене розташування внутрішніх органів, } \\
\text { декстрокардія, дефект міжшлуночкової перегородки }\end{array}$ & \\
\hline & $\begin{array}{l}1 \text { - транспозиція великих артерій, множинні } \\
\text { дефекти міжшлуночкової перегородки }\end{array}$ & \\
\hline & 1 - тетрада Фалло & \\
\hline & 7 - дефект міжшлуночкової перегородки & \\
\hline & $\begin{array}{l}1 \text { - дефект міжшлуночкової перегородки, ліва верхня } \\
\text { порожниста вена, що дренується у коронарний синус }\end{array}$ & \\
\hline
\end{tabular}

підозрено правосторонню дугу аорти з лівосторонньою артеріальною протокою та аберантною лівою підключичною артерією (ПрДА, ЛАП, АЛПА), у 8 (11,4\%) подвійну дугу аорти (ПДА), у 52 (74,3\%) випадках ізольоване СК, у 18 (25,7\%) - поєднане з іншими ВВС.

У 21 (30\%) випадку було проведено МРТ серця плода. Із них у 14 випадках діагноз ПрДА, ЛАП, АЛПА та у 2 випадках ПДА було підтверджено. У 2 випадках ПрДА, ЛАП, АЛПА змінено на ПДА, в одному - ПДА на ПрДА, ЛАП, АЛПА. Середній термін гестації при проведенні МРТ плода становив $30 \pm 3$ т.г. (від 24-го до 37-го т.г.). У 8 випадках МРТ не проводили, оскільки в 1 - діагноз було знято на повторній ЕхоКГ, у 7 - обстеження не вдалось провести через надмірну активність плода або через погане самопочуття вагіт-

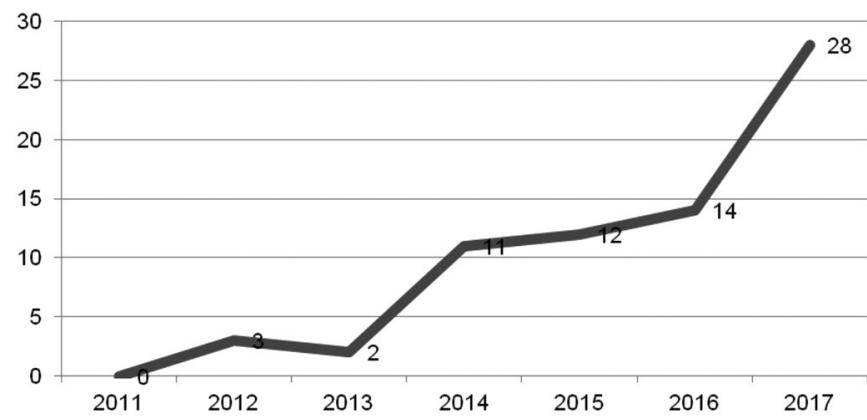

Рис. 1. Щорічне зростання кількості пренатально діагностованих CK них. Усього з 2012 по 2017 рр. діагноз СК було знято у 5 випадках (3 випадки у 2017 р.), з яких у 3 - повторними ЕхоКГ плода і в 2 - методом МРТ.

3 усіх пацієнтів із підтвердженим діагнозом СК лише в однієї дитини з діагнозом ПДА спостерігалися значні клінічні симптоми відразу після народження, коли через виражену дихальну недостатність дитина потребувала негайної інтубації та проведення хірургічного лікування на першу добу життя. В однієї дитини з огинаючою дугою аорти після народження спостерігалися стридорозне дихання, гавкаючий кашель і порушення ковтання. У всіх інших дітей симптоми наростали поступово та найраніше з'являлися на 3-му місяці життя. Всього симптоми з'явились у 13 випадках на момент проведення дослідження.

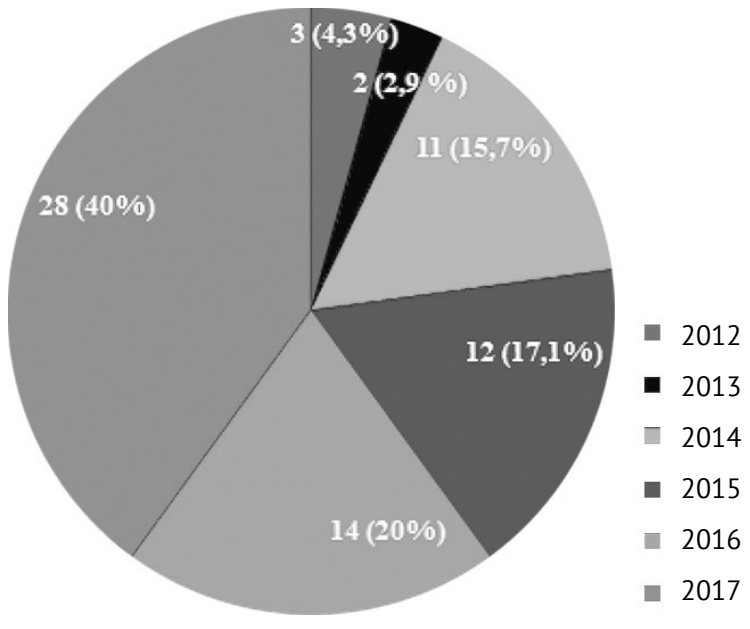

Рис. 2. Співвідношення кількості пренатально діагностованих CK 
Все викладене вище дозволяе зробити висновок, що при пренатально діагностованому СК можна діяти згідно з таким алгоритмом:

При пренатально діагностованому ізольованому СК за відсутності стиснення трахеї згідно з даними МРТ можна планувати народження дитини в спеціалізованому пологовому будинку за місцем проживання згідно з огляду на акушерську ситуацію. При відсутності клінічних симптомів стиснення трахеї та стравоходу (таких, як стридорозне дихання, кашель, порушення ковтання) рекомендовано планову консультацію у ЦДКК у віці 1 місяць. При відсутності клінічних симптомів рекомендовано проведення КТ у плановому порядку не раніше ніж у віці 1 рік. Якщо на КТ виявлено стиснення трахеї більше ніж на $30 \%$, необхідно проводити хірургічне лікування в плановому порядку. При наявності клінічних симптомів рекомендовано невідкладну консультацію в ЦДКК, проведення КТ і хірургічне лікування.

При пренатально діагностованому ізольованому СК зі стисненням трахеї згідно з даними МРТ пологи плануються в спеціалізованому пологовому будинку поблизу кардіохірургічного центру відповідно до акушерської ситуації. При відсутності клінічних симптомів стиснення трахеї та стравоходу (таких, як стридорозне дихання, кашель, порушення ковтання) рекомендовано планову консультацію у ЦДКК у віці 5 днів. При наявності клінічних симптомів рекомендовано проведення КТ та хірургічне лікування.

Якщо СК поєднане з критичними або складними ВВС, алгоритм визначається основною вадою, враховуючи викладене вище. Усунення СК проводиться під час хірургічного лікування іншої ВВС навіть при відсутності симптомів, з попереднім проведенням КT.

Всі діти після народження повинні бути обов'язково проконсультовані генетиком, оскільки до 20\% випад- ків ізольованих СК може поєднуватися з генетичною аномалією, у тому числі із синдромом Ді-Джорджі. Також рекомендована консультація дитини іншими спеціалістами обласної дитячої лікарні для виключення конкуруючої позасерцевої патології.

Висновки. Спираючись на створений на основі проведеного аналізу алгоритм ведення пацієнтів із пренатально діагностованим СК, який заплановано впровадити у практику, можна очікувати підвищення рівня надання допомоги дітям із даною патологією.

\section{Література}

1. Prenatal Sonographic Features of a Double Aortic Arch: Literature Review and Perinatal Management / Trobo D., Bravo C., Alvarez T. et al. // J Ultrasound Med. - 2015 Nov. - Vol. 34 (11). - P. 1921-7.

2. , Fetuses with right aortic arch: a multicenter cohort study and meta-analysis / D’Antonio F., Khalil A., Zidere V. et al. // Ultrasound Obstet Gynecol. - 2016 Apr. - Vol. 47 (4). - P. 423-32.

3. Prenatal diagnosis of vascular rings / Jain S., Kleiner B., Moon-Grady A. et al. // J Ultrasound Med. - 2010 Feb. Vol. 29 (2). - P. 287-94.

4. Prenatal diagnosis and outcome of right aortic arch without significant intracardiac anomaly / Razon Y., Berant M., Fogelman R. et al. // J Am Soc Echocardiogr. - 2014 Dec. - Vol. 27 (12). - P. 1352-8.

5. Vascular rings / Backer C. L., Mongŭ M. C., Popescu A. R. et al. // Semin Pediatr Surg. - 2016 Jun. - Vol. 25 (3). P. 165-75. doi: 10.1053/j.sempedsurg.2016.02.009. Epub 2016 Feb 22.

6. Congenital vascular rings: a clinical challenge for the pediatrician / Licari A., Manca E., Rispoli G. A. et al. // Pediatr. Pulmonol. - 2015. - Vol. 50. - P. 511.

7. Vascular Ring Diagnosis and Management: Notable Trends Over 25 Years / Evans W. N., Acherman R. J., Ciccolo M. L. et al. // World J Pediatr Congenit Heart Surg. - 2016 Nov. - Vol. 7 (6). - P. 717-720.

\section{Effect of prenatal diagnosis of the vascular ring on perinatal management and treatment}

\section{Pavlova A.}

GI «The scientific-practical children's cardiac center» (Kyiv)

Objective. The purpose of the study is to create an algorithm for perinatal management of patients with prenatal diagnosis of the vascular ring (VR).

Materials and methods. From 2004 to 2017 was performed 7740 primary fetal echocardiograms. Since 2016 was performed 21 fetal magnetic tomograms (MRI) in the diagnosis of VR.

Results and discussion. In $70(0.9 \%)$ cases was diagnosed VR. Two children had symptoms of compression of the trachea and esophagus immediately after birth; the others children had gradually increased symptoms since the 3rd month of life. The symptoms were noted in 13 children. After analisis the algorithm for perinatal management of patients with prenatal diagnosis of the VR has created. The absence of compression of the trachea on the fetal MRI allows us to plan births in the regional delivery department. If child hasn't no symptoms after birth, we plane the surgical treatment with tracheal compression on computed tomography (CT) more than $30 \%$. If child has symptoms, we plane an urgent consultation at the Center. The presence of compression of the trachea on the fetal MRI require births near the cardiosurgical center. If children has symptoms, we plane the surgical treatment. The other congenital heart disease (CHD) and VR treat at the same time. 
Conclusions. When the new algorithm for managing patients with VR will be introduce, the level of care for children with VR will be higher.

Key words: vascular ring, prenatal diagnosis, echocardiography, magnetic resonance imaging, computer tomography.

\title{
Влияние пренатального диагноза сосудистого кольца на перинатальное ведение и лечебную тактику
}

\author{
Павлова А. О. \\ ГУ ««Научно-практический медицинский центр детской кардиологии и кардиохирургии МЗ Украины» (Киев)
}

Цель работы - на основе проведенного анализа эффективности пренатальной диагностики сосудистых колец (CK) и оценки клинического состояния пациентов составить алгоритм перинатальной тактики.

Материалы и методы. С 2004 по 2017 гг. было проведено 7740 первичных эхокардиографий (ЭхоКГ) плода. С 2016 г. проведена 21 магнитно-резонансная томография (МРТ) плода при диагностике СК.

Результаты и обсуждение. В 70 (0,9\%) случаях было диагностировано СК. У двух детей наблюдались симптомы сдавления трахеи и пищевода сразу после рождения, у других - нарастали постепенно с 3-го месяца жизни. Всего симптомы отмечались у 13 детей. Был проведен анализ и разработан алгоритм ведения пациентов с пренатально диагностированным СК. Отсутствие сдавления трахеи на МРТ плода позволяет планировать роды в роддоме по месту жительства и при отсутствии симптомов консультировать ребенка в Центре в 1 месяц жизни с плановым хирургическим лечением при сжатии трахеи на компьютерной томографии (KT) более 30\%. При появлении симптомов рекомендована неотложная консультация в Центре, при наличии сдавления трахеи на МРТ плода - роды вблизи кардиохирургического центра, при появлении симптомов - неотложная КТ и хирургическое лечение. Если СК не изолированное, его устранение проводится во время хирургического лечения другого врожденного порока сердца (ВПС).

Выводы. При внедрении в практику созданного алгоритма ведения пациентов с СК можно ожидать повышения уровня оказания помощи детям с данной патологией.

Ключевые слова: сосудистые кольца, эхокардиография, пренатальная диагностика, магнитно-резонансная томография, компьютерная томография. 